\title{
Heavy Equipment Rental Schedule Report Application Using Visual Basic.Net and MySQL Database
}

\author{
Syerlie Annisa ${ }^{1, *},{ }^{*}$ Yurita Delvianti ${ }^{2}$
}

1,2AMIK Mitra Gama, Duri, Indonesia

\begin{tabular}{l} 
Article Information \\
\hline Article History: \\
Accepted by the Editor: November 30, 2021 \\
Final Revision: December 29, 2021 \\
Published Online: December 31, 2021 \\
Keywords \\
\hline Application \\
Timesheet \\
Visual basic \\
Databases \\
MySQL \\
Correspondence \\
\hline E-mail: syerlieannisa@gmail.com*
\end{tabular}

E-mail: syerlieannisa@gmail.com*

\section{A B S T R A C T}

The heavy equipment business in Indonesia is again excited in line with the increasing demand for heavy equipment by various sectors such as the mining sector, the agro-industry sector, and the construction sector. PT. Petronesia Benimel is one of the business fields engaged in renting heavy equipment. The management of the heavy equipment rental schedule to other companies has been carried out using a computerized system, namely using the Microsoft Excel application which is still not optimal in integrating, calling and processing data at once. Using these applications independently results in the management of heavy equipment rental reports being constrained because tenant data and rental management are often out of sync. The application uses Visual Basic programming language and MySQL database supported by research and product development methods and waterfall development models. Based on the trial results of using a schedule report application that can make it easier for staff to manage heavy unit rental schedules from various partner companies (stakeholders) so that better reports are obtained.

This is an open access article under the CC-BY-SA license

\section{Introduction}

The heavy equipment rental business in Indonesia has been in great demand in recent years. It is in line with the increasing domestic heavy equipment rental market as one of the impacts of the increasing demand for heavy equipment from various sectors such as the mining sector, the agro-industry sector, and the construction sector. PT. Petronesia Benimel, Bengkalis Regency, Riau Province, is one of the business fields engaged in the rental of heavy equipment. The management of heavy equipment rental schedules to other companies is carried out using a computerized system, using the Microsoft Excel application. However, in its implementation, it has not been maximized because the storage and management of heavy equipment rental reports have not used a database, so it is challenging to integrate, retrieve and process rental data at once, the data that is managed is often not following the conditions in the field. Therefore, a unit rental schedule report application was built to facilitate staff in managing the rental of heavy equipment owned by the company using Visual Basic.Net version 7.0 programming language and MySQL database.

The research objectives are as follows: (1) Make a report on the rental schedule for heavy equipment using an application at PT. Computerized and integrated Petronesia Benimel; and (2) Designing applications to facilitate data management, facilitate access to storage and search for the resulting data to be accurate. 
The application concept consists of humans, computers, information technology, and work procedures [1]. In contrast, the concept of scheduling is an activity that aims to monitor or observe something [2]. Microsoft Visual Studio is an integrated development environment by Microsoft Corporation. Microsoft Visual Studio can develop applications in machine language that runs on Windows. In order to build an application with good storage and management, database support is needed. This study used MySQL database. MySQL is a software/application software from the SQL programming language or multithreaded DBMS and many users [3].

\section{Method}

The research was conducted at PT. Petronesia Benimel is located in Mandau District, Bengkalis Regency, Riau Province. Research at this company uses research and development, namely research that aims to produce a new product or improve the previous product [4]. This research has two types, namely the development of product design and evaluation, and the second type examines previous development programs [5]. This development model is used based on considerations because it has a systematic and wellstructured procedure [6]. This type of research and development has been successfully carried out in various research cases and in various fields such as education, industry, health, and other fields [7]. For product development in this study using the waterfall model with the following stages: (1) requirements definition;

(2) system and software design; (3) implementation and unit testing; (4) integration and system testing; and (5) operation and maintenance.

\section{Results and Discussion}

\subsection{Requirements Definition}

The activities carried out at this stage are: (1) Studying the ongoing heavy equipment rental report management activities; (2) Identifying problems in managing heavy equipment rental reports that arise. Obstacles were found in file management that had not used the database and had not been well organized, and (3) Determine user requirements for the system to be built. Based on the results of interviews and observations, the functional requirements obtained are login pages, swamper data collection forms, equipment data collection forms, operator data collection forms, work location data collection forms, schedule data collection forms (timesheets) and reports from each data management result.

\subsection{System and Software Design}

\subsubsection{Context Diagram}

A context diagram represents the application system that displays the relation between the system and all the entities involved in a system [8]. In general, the design can display the application system as a whole which can be seen in context diagrams. A context diagram contains only one process, which represents the process of the entire application system. The context diagram showing the workflow and documents can be seen in Figure 1 below. 


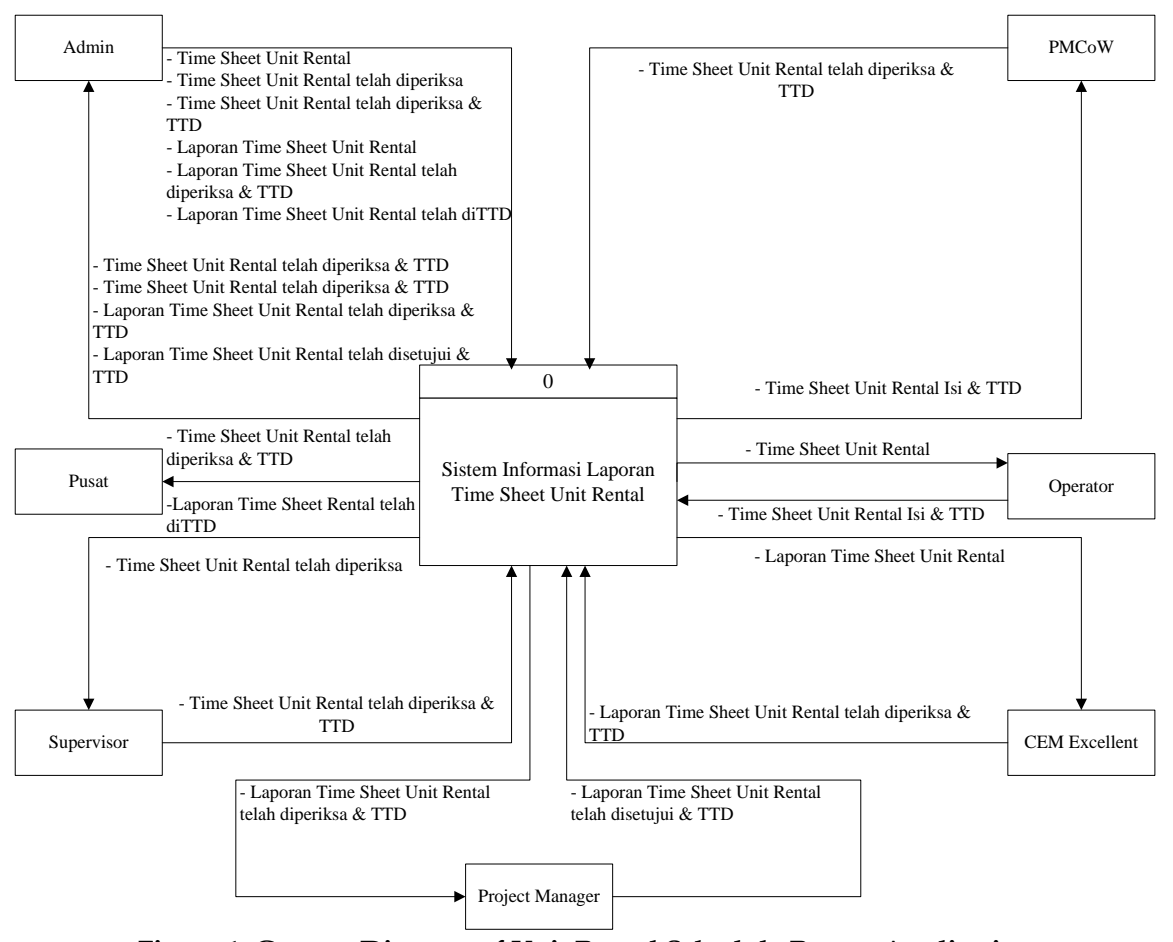

Figure 1. Context Diagram of Unit Rental Schedule Report Application

\subsubsection{Data Flow Diagram}

The data flow diagram is a data logic model to represent the origin and destination of the data leading to the output of the system [9]. The data flow diagram that shows the details of the workflow and documents in this application can be seen in Figure 2 as follows.

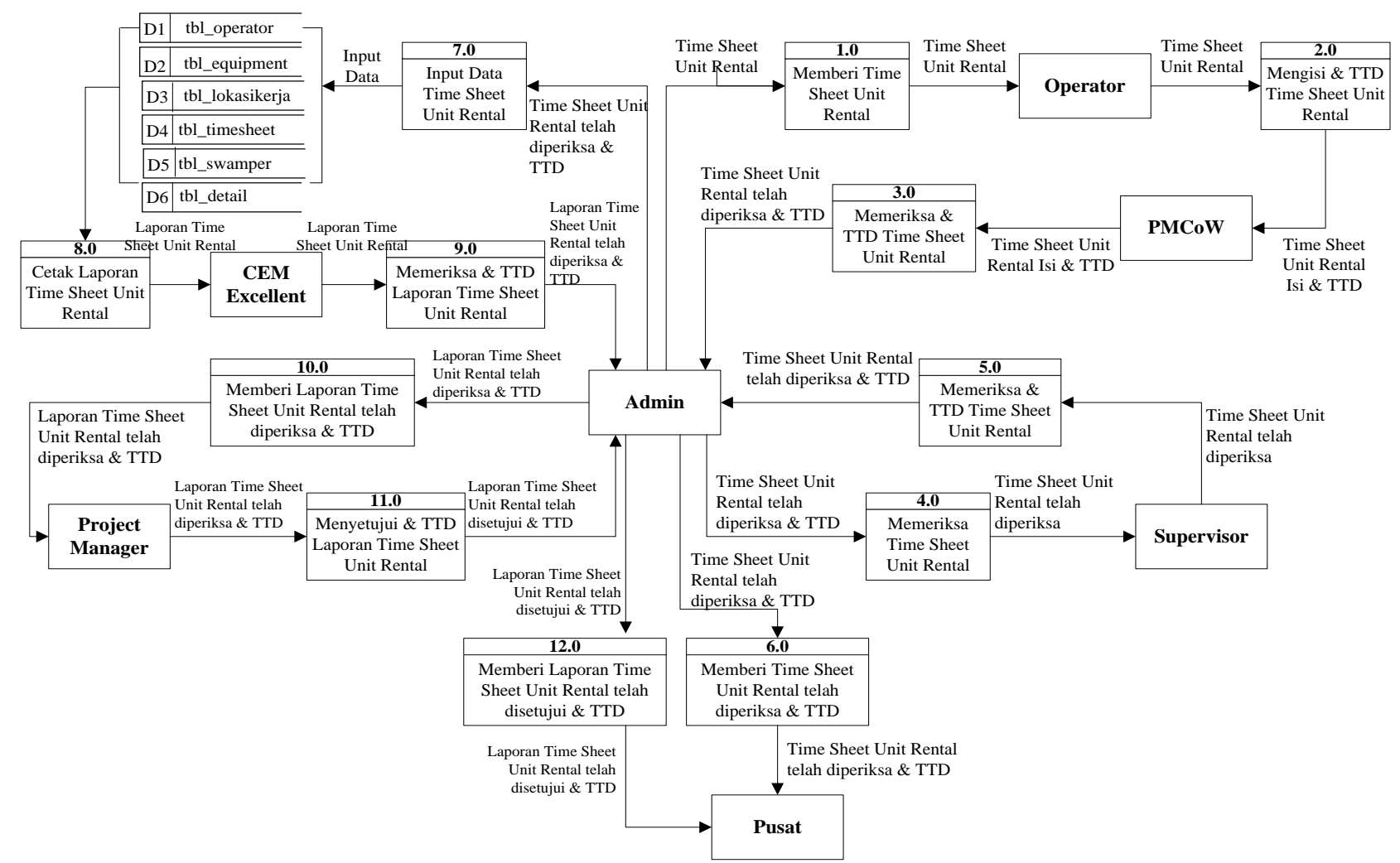

Figure 2. Data Flow Diagram of Unit Rental Schedule Report Application 


\subsubsection{Entity Relation Diagram}

A relation diagram describes the relation between objects in a database against entities or related parties or a database design by explaining groups of data and relation between data, where this diagram has two main components, namely entities and relation [10]. The relation diagram between entities that shows the details of the workflow and documents in this application can be seen in Figure 3.

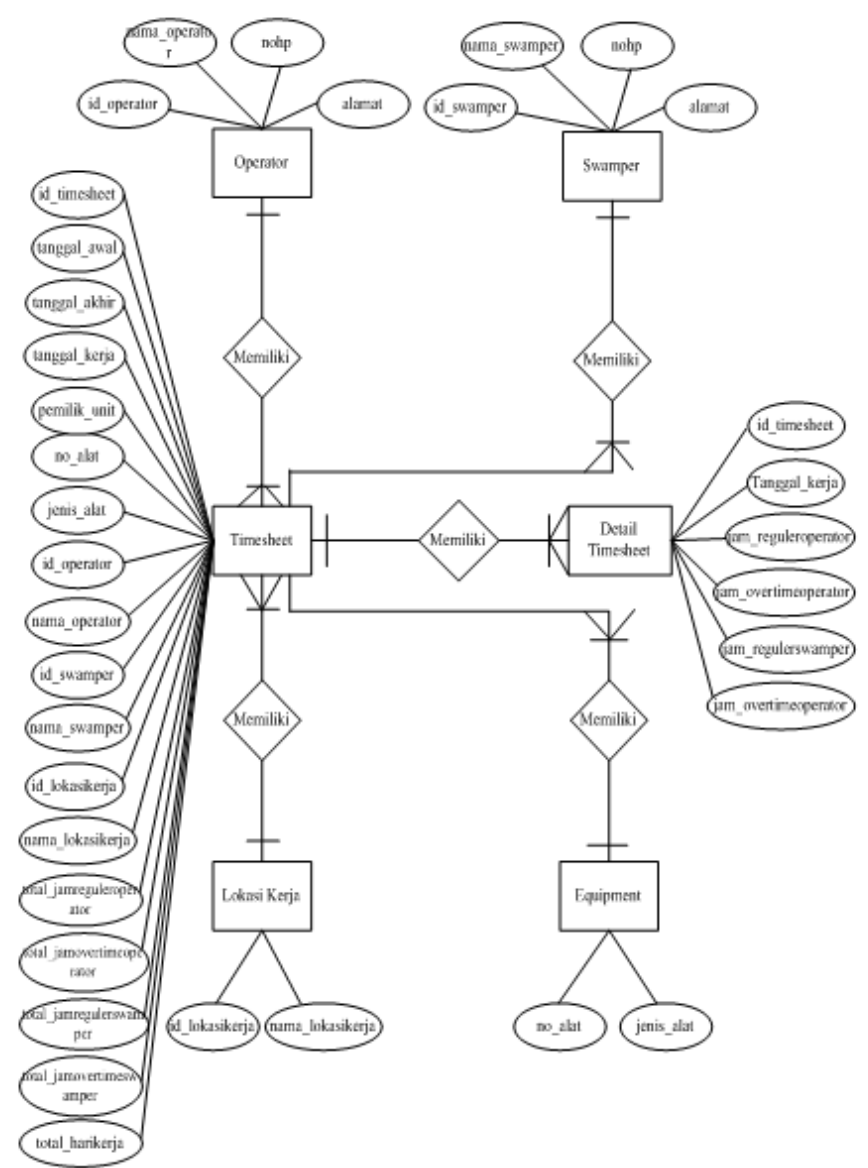

Figure 3. Data Flowchart of Unit Rental Schedule Report Application

\subsubsection{User Interface}

Figure 4 is the display of the swamper data collection form. This swamper data collection page will appear after the user (admin) has successfully logged into the application. In this form, the user can add, delete, and change data regarding the swamper responsible for the heavy equipment for rent. 


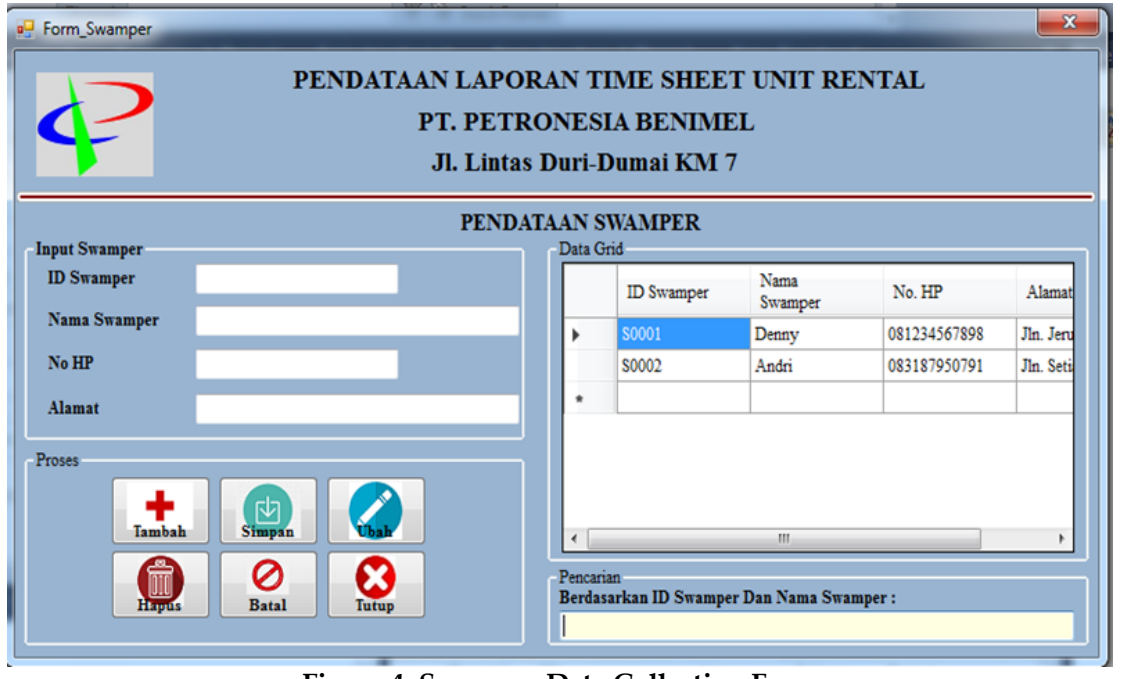

Figure 4. Swamper Data Collection Form

Figure 5 is an equipment data collection form. This form is a form page for managing data on rental heavy equipment units. In this form, users can add, delete, and change data regarding heavy equipment units so that all heavy equipment data they have can be traced.

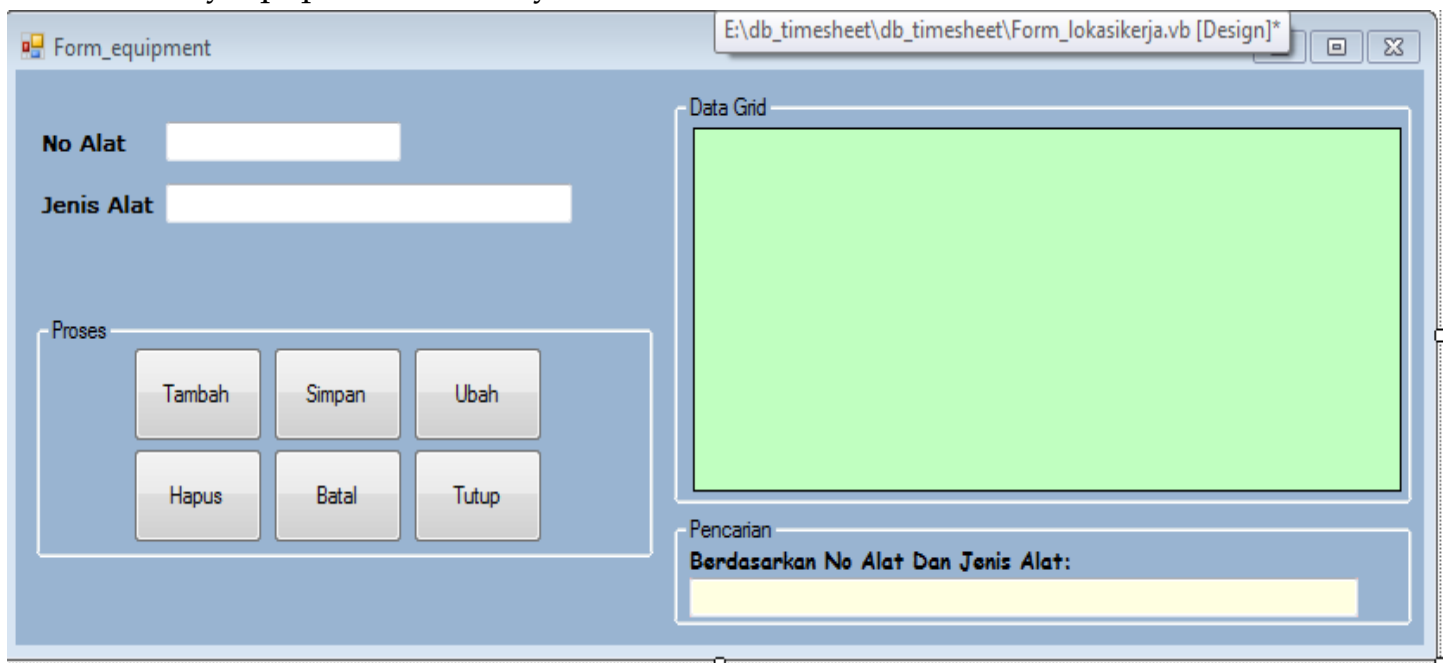

Figure 5. Equipment Data Collection Form

Figure 6 is the operator data collection form. This form is a form page for managing operator data responsible for the rental heavy equipment unit. In this form, the user can add, delete, and change data regarding the operator of the heavy equipment unit. 


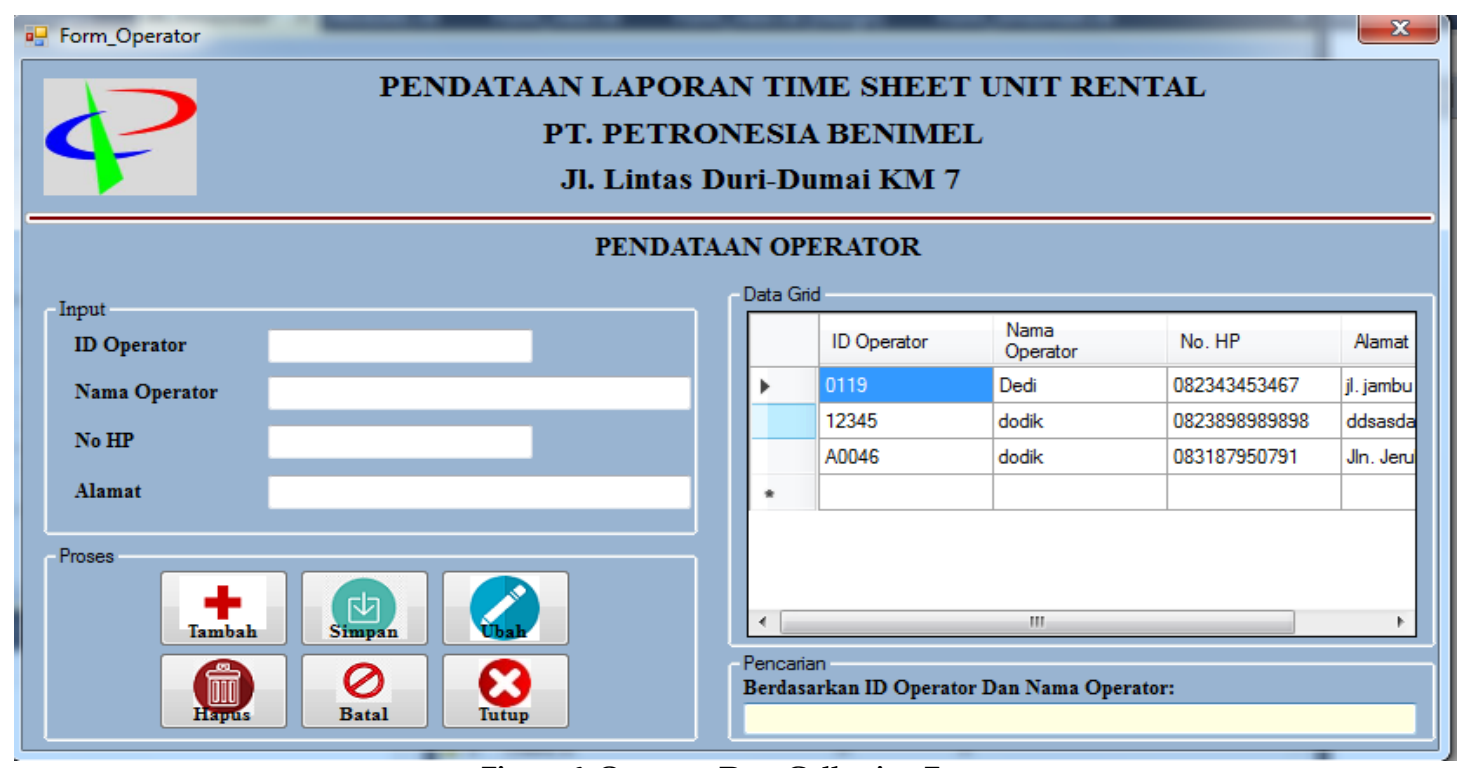

Figure 6. Operator Data Collection Form

Figure 7 is a work location data collection form. This form is a page for managing location data of heavy equipment units to be used by tenants (stakeholders). In this form, users can add, delete, and change data regarding the work location of the heavy equipment unit.

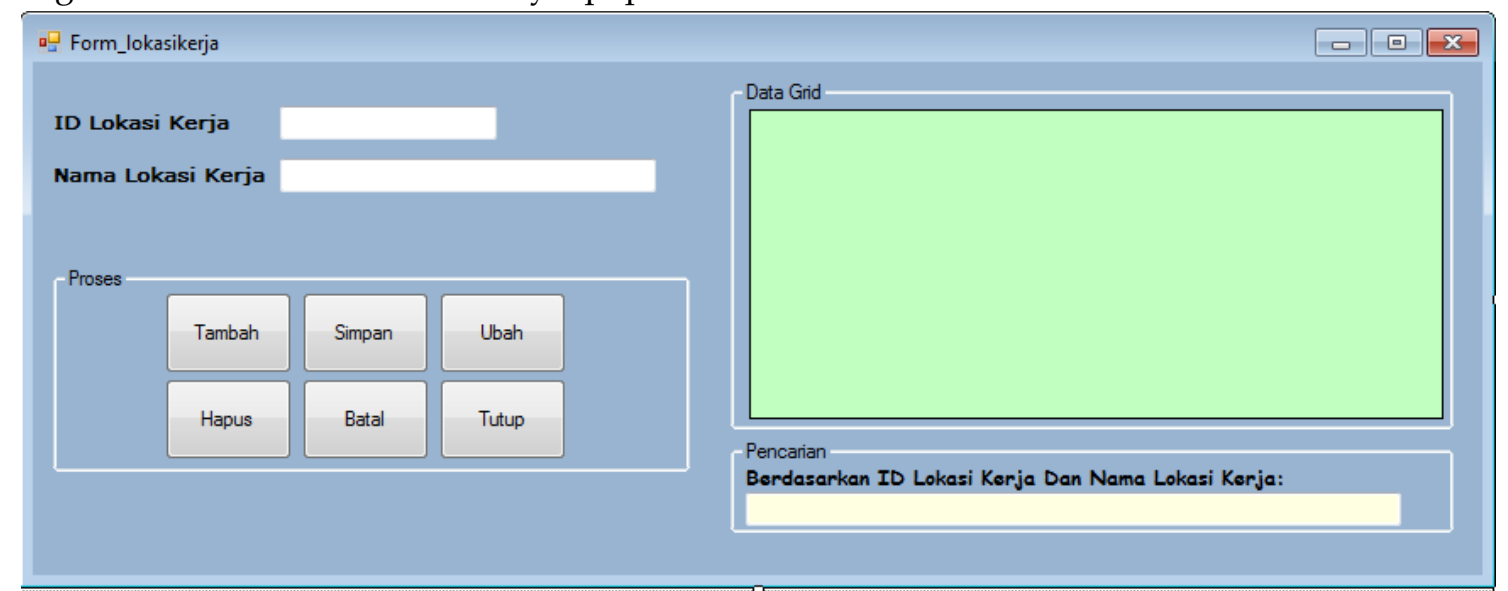

Figure 7. Work Location Data Collection Form

Figure 8 is a form for the data collection on the rental schedule for heavy equipment units. This form manages the data on the rental schedule for each unit of heavy equipment used by the tenants (stakeholders) so that the rental information is more structured, systematic, and can be adequately monitored. In this form, users can add, delete, and change data regarding the rental schedule for heavy equipment units. 


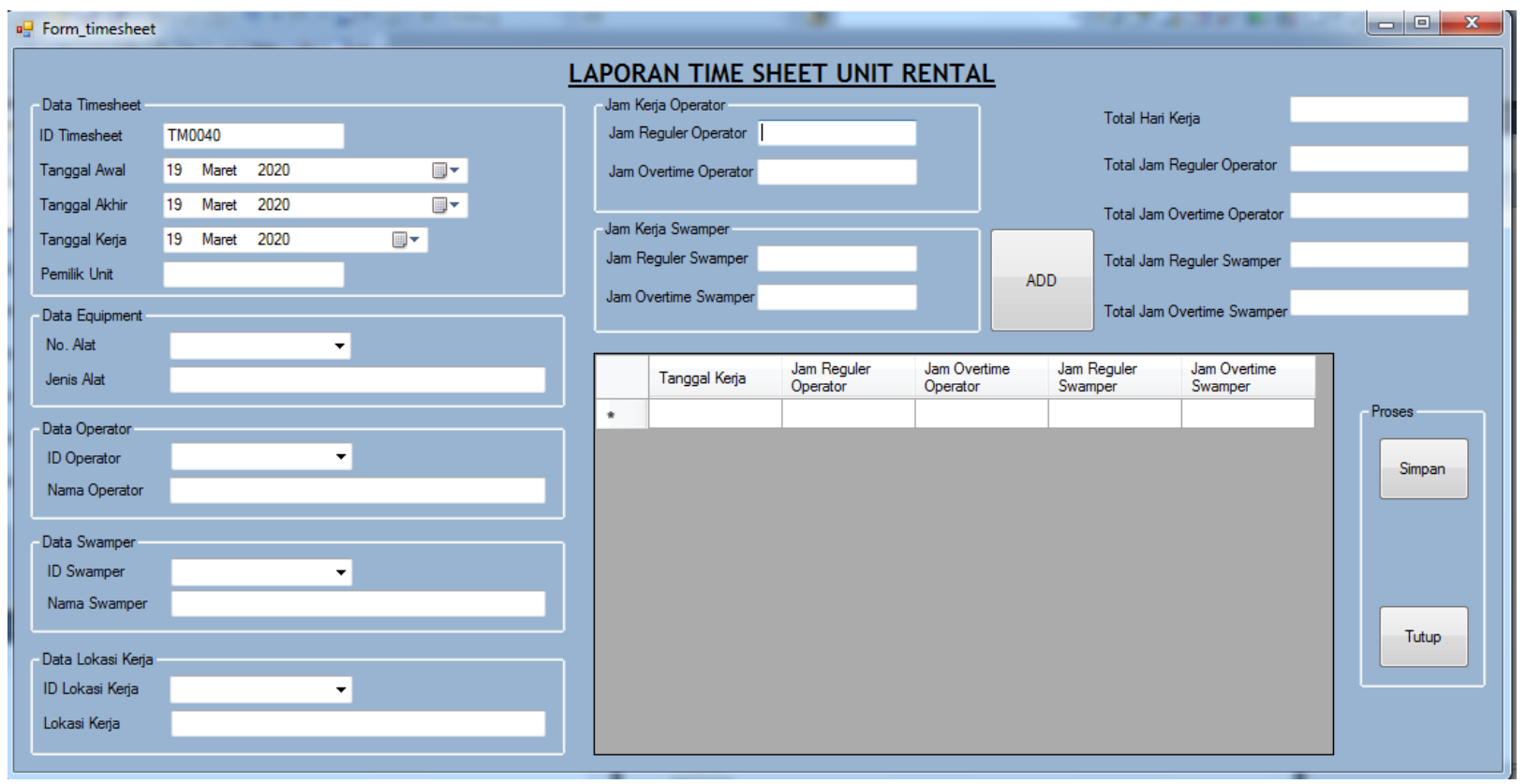

Figure 8. Data Collection Form for Heavy Equipment Unit Rental Schedule

Admin has the duties and responsibilities to manage (add, change, delete, save, and print reports) of each data needed to display information on the rental schedule for heavy equipment units by user companies. Supervisors have access rights to be able to monitor and directly display information and reports from all of these data and can print the required reports without having to wait from the admin so that based on these reports, strategic decisions can be made regarding optimal heavy equipment rental for the company's progress.

\subsection{Implementation and Unit Testing}

This stage is implementing the design results in the Visual Basic.Net programming language. At this stage, a trial is carried out on the application to identify errors or debugging from the information system for managing heavy equipment rental reports before testing its usefulness in the next stage.

\subsection{Integration and System Testing}

In this stage, the integration and application of information systems is carried out to find and analyze the extent to which the applications produced can meet users' needs. System integration combines all program units into a whole unified program. Furthermore, system testing is carried out to determine whether the application is feasible to be implemented and following the standard requirements defined at an early stage.

\subsection{Operation and Maintenance}

After designing the application according to the standard user needs, then distribution is carried out to the admin and leadership of PT. Petronesia Benimel will be applied and evaluated to review whether the new application meets user goals. If there is an error, the application is corrected according to the error that occurred.

\section{Conclusion}

Based on the results of the research and design of the application program until the stage of use, the researchers took several conclusions, namely: (1) Application of the heavy equipment unit rental schedule report designed using the Visual Basic.Net programming language and MySQL database can provide convenience for admins in processing schedule reports. rental of heavy equipment units to make it better; 
and (2) By using a new system using a database, it can minimize the occurrence of data duplication and can make it easier to search for data on the rental schedule for heavy equipment units.

\section{References}

[1] S. Annisa and Yohana, "Sistem Informasi Penarikan Mobil Jatuh Tempo pada PT . Capella Multidana - Duri Menggunakan Bahasa Pemrograman Visual Basic," Jurnal Jaringan Sistem Informasi Robotik.,vol. 5, no. 1, pp. 22-27, 2021.

[2] S. Annisa, "Desain Sistem Penjadwalan Mata Kuliah Menggunakan Bahasa Pemrograman PHP/MySQL (Studi Kasus : STAIN Bukittinggi)," Jurnal Jaringan Sistem Informasi Robotik., vol. 3, no. 1, pp. 161-168, 2019.

[3] A. A. B. S. Pramono and A. W. Utami, "Rancang Bangun Sistem Informasi Praktik Industri di Jurusan Teknik Informatika UNESA Berbasis Website," Jurnal Jaringan Sistem Informasi Robotik.vol. 8, pp. 70-78, 2018.

[4] H. Ardiyanto and S. Fajaruddin, "Tinjauan atas artikel penelitian dan pengembangan pendidikan di Jurnal Keolahragaan," Jurnal Keolahragaan, vol. 7, no. 1, pp. 83-93, 2019, doi: 10.21831/jk.v7i1.26394.

[5] Hanafi, “Konsep Penelitian R \& D Dalam Bidang Pendidikan," Saintifika Islamica : Jurnal Kajian Keislaman., vol. 4, no. 2, p. 130, 2017.

[6] S. Annisa, "Pengembangan Lembar Kerja Siswa Berbasis Model Pembelajaran Kooperatif Pada Mata Pelajaran Keterampilan Komputer Dan Pengelolaan Informasi (KKPI)," Jurnal Jaringan Sistem Informasi Robotik., vol. 1, no. 01, pp. 8-17, 2017.

[7] A. D. Pangesti, "Research and Development: Penelitian yang Produktif Dalam Dunia Pendidikan," Researchgate, vol. 5, no. 1, pp. 1-8, 2019, doi: 10.13140/RG.2.2.28521.44640.

[8] R. Nurmalina, "Perencanaan dan Pengembangan Aplikasi Absensi Mahasiswa Menggunakan Smart Card Guna Pengembangan Kampus Cerdas ( Studi Kasus Politeknik Negeri Tanah Laut )," Jurnal Integrasi, vol. 9, no. 1, pp. 8491, 2017.

[9] S. Annisa and F. Derisfy, "Sistem Informasi Pengolahan Data Hasil Unloading Oily Sand dari Central Gate Station," vol. 3, no. 2, pp. 257-263, 2019.

[10] I. Efendi and S. Annisa, "Penerapan Media Pembelajaran Game Berbasis Android untuk Pengenalan Abjad," Jaringan Sistem Informasi Robotik, vol. 2, no. 02, pp. 137-145, 2018. 